\title{
STUDI PRODUKSI INDUSTRI KERUPUK KULIT DI JORONG KAPALO KOTO NAGARI TANJUNG BARULAK KECAMATAN BATIPUH KABUPATEN TANAH DATAR
}

\author{
Melda Sari ${ }^{1}$, Ernawati ${ }^{2}$, Ratna Wilis ${ }^{2}$ \\ Program Studi Pendidikan Geografi, \\ Fakultas Ilmu Sosial, Universitas Negeri Padang \\ Email: meldasari8@gmail.com
}

\begin{abstract}
Abstrak
Penelitian ini bertujuan untuk mendapatkan data dan informasi tentang 1) proses produksi kerupuk kulit, 2) kendala-kendala produksi industri kerupuk kulit, 3) upaya-upaya untuk mengatasi kendala produksi industri kerupuk kulit. Jenis penelitian ini adalah deskriptif kualitatif. Informan dalam penelitian ini adalah 8 orang pengusaha kerupuk kulit, 3 orang tenaga kerja, 3 orang pembeli, 1 orang Wali Nagari Tanjung Barulak dan 1 orang Kepala Dinas Kopperindag Kabupaten Tanah Datar. Teknik pengumpulan data melalui observasi, wawancara, dan dokumentasi. Teknik analisis data melalui reduksi data, penyajian data, dan pengambilan kesimpulan. Hasil penelitian menemukan: 1), (a) proses produksi kerupuk kulit dimulai dari proses perebusan, pembuangan bulu, pengeringan, dan perendaman dengan bumbu dan dilanjutkan dengan penggorengan (b) sumber bahan baku berasal dari tempat pemotongan sapi Padang Panjang dan Solok, (c) modal berasal dari dana pribadi, pinjaman Bank, dan koperasi, (d) tenaga kerja berasal dari daerah sekitar, (e) pemasaran dilakukan di daerah setempat, toko oleh-oleh, dan Supermaket. 2), kendalakendala produksi industri kerupuk kulit: (a) proses pengeringan atau penjemuran pada hari hujan (b) penyediaan bahan baku kurang lancar, (c) kurangnya modal untuk pengembangan usaha (d) kurangnya promosi dan belum luasnya wilayah pemasaran. 3), upaya-upaya mengatasi kendala produksi industri kerupuk kulit : (a) dengan menggunakan panas gas tungku, (b) mencari bahan baku keluar Kabupaten, (c) meminjam uang ke koperasi atau Bank, (d) memperluas pemasaran.
\end{abstract}

Kata Kunci : Produksi, Industri Kerupuk Kulit.

\section{Abstract}

This study is aimed to obtain data and information about 1) the process of skin cracker production, 2) the obstacles of industrial production of skin crackers, 3) efforts to overcome the constraints of industrial production of skin crackers. The type of this research is descriptive qualitative. Informants in this research are 8 leather crackers industrialist, 3 laborers, 3 buyers, 1 Wali Nagari Tanjung Barulak and 1 department of Kopperindag Tanah Datar. The data are collected through observation, interviews, and documentation. The data are analyzed through data reduction, data presentation, and conclusion. The result of the research are: 1) (a) the production process skin crackers starts from the of feather dumping, boiling, drying, and soaking with spices and followed by a frying pan. (b) the source of raw materials comes from the slaughterhouses of Padang Panjang and Solok, (c) the financial capital comes from private funds, bank loans, and cooperatives fund, (d) the labor is local inhabitants, (e) marketing is done in local area, gift shop, and Supermaket. 2) result is about the obstacles of skin cracker production industry: (a) drying process on rainy days (b) poor supply of raw materials, (c) lack of financial capital for business development (d) lack of promotion and lack of marketing area. 3) efforts to overcome the obstacles of industrial production of skin crackers: (a) by using gas furnace heat, (b) seeking raw materials out of the Regency; (c) borrowing money to cooperatives or Banks; (d) expanding the marketing.

Keywords: Production, Industrial Leather Cracker.

\footnotetext{
${ }^{1}$ Mahasiswa Program Studi Pendidikan Geografi untuk wisuda Maret 2018

${ }^{2}$ Dosen Jurusan Geografi Fakultas Ilmu Sosial Universitas Negeri Padang: Pembimbing I Dr. Ernawati, M.Si.dan Pembimbing II Ratna Wilis S.Pd. M.P.
} 


\section{PENDAHULUAN}

Di Indonesia industri pangan sering dipandang sebelah mata. Beberapa makanan tradisional yang dikerjakan oleh pengusahapengusaha kecil, banyak yang hanya sekedar mengemas dan melupakan fungsi-fungsi dari sebuah kemasan dalam persaingan pasar saat ini. Padahal diera global ini, persaingan dagang semakin ketat dengan masuknya produk-produk asing yang memiliki kemasan yang menarik dan harga yang bersaing. Membuat produk Indonesia kalah bersaing dalam mendapatkan kepercayaan dari konsumen akan kualitas produk.

Kerupuk adalah salah satu makanan khas Indonesia yang diminati banyak orang. Baik dari golongan menengah kebawah hingga dari golongan menengah ke atas. Mulai dari anak kecil hingga orang dewasa. Tidak heran, sampai saat ini bisnis kerupuk masih banyak diproduksi dengan peminatnya yang semakin banyak.

Kerupuk pada umumnya adalah makanan ringan yang dibuat dari adonan tepung tapioka dicampur bahan perasa seperti udang dan ikan. Sebutan kerupuk dibeberapa negara antara lain krupuk/kerupuk/kropoek di Indonesia, keropok di Malaysia, Kropek di Filiphina, bánh phông tôm di Vietnam merupakan makanan ringan (snack) di beberapa negara Asia (Anonymous, 2010). Kerupuk bertekstur garing dan dijadikan sebagai makanan selingan, pelengkap untuk berbagai makanan Indonesia seperti nasi goreng, gado-gado, soto, rawon, bubur ayam dan lain lain dan bahkan orang menganggap kerupuk sebagai lauk sehari-hari.

Kerupuk biasanya dijual dalam kemasan yang belum digoreng (kerupuk mentah) atau dalam kemasan yang sudah digoreng (kerupuk matang). Ada dua jenis kerupuk yang dikenal dimasyarakat, yaitu kerupuk dengan bahan baku nabati (seperti ; kerupuk singkong, kerupuk bawang, kerupuk puli, rempeyek, rengginang, kerupuk gendar, kerupuk aci, kemplang, rengginang, emping melinjo ((Gnetum gnemon) dan karak) dan kerupuk dengan tambahan bahan pangan hewani (seperti ; kerupuk udang, kerupuk ikan dan kerupuk kulit (jangek/rambak) (Anonymous, 2010). Sedangkan kerupuk kulit atau yang dikenal dengan nama kerupuk jangek/rambak adalah kerupuk yang tidak dibuat dari adonan tepung tapioka, melainkan dari kulit sapi, kerbau, kelinci, ayam atau kulit ikan yang dikeringkan (Anonymous, 2011).

Kerupuk jangek atau kulit adalah salah satu jenis kerupuk olahan makanan warisan nenek moyang asli Indonesia. Umumnya kerupuk ini hanya dikenal oleh masyarakat Sumatra dan Jawa. Dengan perkembangan yang begitu pesat kini kerupuk kulit bisa kita temukan dimana saja. 
Membuat kerupuk kulit merupakan salah satu aktifitas ekonomi yang tergolong tradisional. Bahan bakunya berasal dari kulit sapi atau kerbau. Tapi para pengolah lebih cenderung menggunakan kulit sapi, karena kulit sapi ini paling mudah didapatkan di pasaran. Kulit merupakan bagian dari hewan yang kurang dimanfaatkan oleh masyarakat Indonesia sebagai bahan baku pangan. Namun, kulit dapat diolah kembali menjadi makanan sehingga menjadikan suatu kesempatan untuk melakukan kegiatan usaha dalam pembuatan kerupuk kulit dan berpeluang besar untuk memasuki perdagangan dipasar.

Tahap produksinya yaitu tahap proses pembuangan bulu, pengembangan kulit, perebusan, pengeringan, dan perendaman dengan bumbu untuk kerupuk kulit mentah atau dilanjutkan penggorengan untuk kerupuk kulit siap dikonsumsi. Makanan kerupuk kulit ini mengandung unsur ekonomi yang berkaitan dengan aspek budaya dan seni, karena keberadaannya adalah sebagai warisan budaya dan kebanggaan bersama bagi masyarakat setempat.

Di Sumatera Barat sendiri khususnya Kota Padang, pada umumnya sudah banyak pengusaha yang menjalankan usaha kerupuk jangek ini dan bahkan menjadikan makanan ini sebagai salah satu oleholeh khas daerah. Begitu juga dengan beberapa industri pengolahan kerupuk kulit yang ada di Jorong Kapalo Koto Nagari Tanjung Barulak meskipun skalanya masih Industri Rumah Tangga (IRT). Meskipun demikian industri kerupuk kulit yang ada di Jorong ini terus mengembangkan usaha kerupuk kulit untuk meningkatkan penghasilan keluarga.

Industri kerupuk kulit ini dulunya sangat berkembang karena belum banyak pesaingan pasar dengan industri-industri lain sehingga dapat menguasai pasar walaupun hanya memasarkan di daerah yang tidak jauh dari tempat produksinya. Dilihat dari kelebihannya, usaha kerupuk kulit yang ada di Jorong Kapalo Koto ini memiliki cita rasa yang renyah dan garing bila digigit, serta kerupuk kulit ini banyak dinikmati oleh masyarakat luas, bahkan rumah makan ada juga yang menyajikan kerupuk kulit sebagai tambahan pelengkap makan nasi. Semua itu tidak terlepas dari pemilihan bahanbahan yang bagus dan berkualitas. Usaha kerupuk kulit ini juga membawa dampak positif, dan dari sisi kesehatan kerupuk kulit juga sangat cocok dikonsumsi bagi yang memiliki penyakit maag.

Produksi merupakan konsep arus (flow concept), yang dimaksud dengan konsep arus adalah produksi merupakan kegiatan yang diukur sebagai tingkatan-tingkatan output per unit periode atau waktu, 
Sedangkan outputnya sendiri selalu diasumsikan konstan kualitasnya. Pemakaian sumber daya dalam suatu proses produksi juga diukur sebagai arus (Miller dan Meiners, 1997).

Industri merupakan bagian dari pembangunan ekonomi nasional suatu negara, baik di Indonesia maupun di negara lain. Industri menurut UU No 5 tahun 1995 tentang perindustrian , yang dimaksud dengan industri adalah kegiatan ekonomi yang mengolah bahan mentah, bahan baku, bahan setengah jadi atau barang jadi menjadi barang dengan yang lebih tinggi untuk penggunanya, termasuk kegiatan rancang bangun dan perekayasaan industri.

Menurut Godam (2006), mengatakan bahwa industri adalah suatu usaha atau kegiatan pengolahan bahan mentah atau barang setengah jadi menjadi barang jadi, barang jadi yang memiliki nilai tambah untuk mendapatkan keuntungan.

Menurut Hermanianto, Nurwahid, \& Azhar (1997) dalam Lula Nadia (2001), salah satu parameter mutu pangan adalah mutunutrisi yang antara lain meliputi kadar protein, kadar lemak, kadar air, kadar abu, dan rendemen.Keberadaan air dalam bahan pangan sangat mempengaruhi penampakan, tekstur, dan citarasa.

Kerupuk kulit tersebut mempunyai kandungan protein sebesar 6,10\%, kadar air sebesar $0,11 \%$, kadar kalsium sebesar $1,88 \%$, daya kembang 372,12\%, skor kerenyahan 5,38 dan skor rasa 6,89 (Widati dkk (2007)).

Bahan baku merupakan bahan dasar untuk menggerakkan sebuah industri karena bahan baku merupakan bahan yang akan di olah dalam kegiatan industri untuk memperoleh barang lain yang lebih tinggi nilainya dalam penggunaanya.

Menurut Soekartawi (2001), bahan bakucepat atau lambatnya proses produksi sangat dipengaruhi oleh kelancaran bahan baku, sebagai unsur untuk memproduksi suatu barang. Dalam kaitannya dengan bahan baku, maka investasi untuk pembelian bahan baku merupakan prioritas pertama bagi perkembangan hasil produksi suatu perusahaan.

$\begin{array}{cccc} & \text { Menurut } & \text { Yulianto } & \text { dalam } \\ \text { Selfia } & \text { Dewi } & \text { (2013) } & \text { modal }\end{array}$
merupakan sejumlah uang yang dibutuhkan suatu badan usaha untuk membiayai kegiatan usahanya. Kebutuhan akan modal merupakan kebutuhan yang sangat vital bagi kehidupan suatu badan usaha. Dengan adanya modal, maka semua pengeluaran untuk membiayai kegiatan usaha dapat dilaksanakan.

Tenaga kerja ialah sesuatu yang mengelola sumber daya alam tersebut dengan menggunakan tenaga dari manusia atau biasa disebut dengan sumber daya manusia. Menurut UUNo.14 tahun 1969 (pasal 1), tenaga kerja adalah tiap orang yang mapu melaksanakan pekerjaan, baik di dalam maupun di 
luar hubungan kerja guna menghasilkan jasa atau barang yang memenuhi kebutuhan masyarakat. Jadi tenaga kerja menurut ketentuan ini meliputi tenaga kerja yang bekerja di dalam maupun di luar hubungan kerja, dengan alat produksi adalah tenaga kerjanya sendiri, baik tenaga kerja fisik maupun fikiran.

Pemasaran berasal dari kata "pasar" yang apabila secara umum mempunyai arti pertemuan antara sipenjual dan sipembeli. Pemasaran adalah suatu kegiatan yang dilakukan baik oleh pengedar barang yang bertujuan untuk memasarkan dengan meningkatkan hasil yang hendak dicapai.

Menurut Freedy Rangkuti
(1997), mengatakan bahwa
pemasaran adalah suatu proses
kegiatan yang dipengaruhi oleh berbagai faktor sosial, budaya, politik, ekonomi, manajerial. Akibat pengaruh dari berbagai faktor tersebut masing-masing individu maupun kelompok mendapatkan kebutuhan dan keinginan dengan menciptakan, menawarkan dan menukarkan produk yang memiliki nilai komoditas.

Kendala adalah suatu masalah atau persoalan yang harus dipecahkan. Dengan kata lain kendala merupakan kesenjangan antara kenyataan dengan suatu yang diharapkan dengan bai atau sesuatu yang menyimpang dari apa yang diharapkan, direncanakan, ditentukanuntuk dicapai sehingga merupakan rintangan menuju tercapainya tujuan.

Upaya adalah usaha, ikhtiar untuk mencapai maksud tertentu. tindakan yang dilakukan seseorang, untuk mencapai apa yang diinginkan atau merupakan sebuah strategi. Sehingga dalam kehidupan manusia selalu melakukan upaya sepanjang hidupnya. Manusia tidak mungkin hidup tanpa tujuan karena manusia selalu memiliki kebutuhan, terutama kebutuhan hidup.

Dilihat dari pengembangannya akhir-akhir ini produksi industri kerupuk kulit yang ada di Jorong Kapalo Koto, Nagari Tanjung Barulak ini mulai menurun dan belum menunjukkan perkembangan yang berarti. Berdasarkan observasi awal yang peneliti lakukan dibeberapa industri kerupuk kulit di Jorong Kapalo Koto Nagari Tanjung Barulak peneliti menemukan dari ke tiga faktor yang ikut berpengaruh dalam proses produksi yang terdiri dari bahan baku, modal, dan tenaga kerja ternyata masing-masing industri memiliki kendala pada faktor-faktor tersebut, meskipun tidak semua faktor ikut berpengaruh.

Selain itu, usaha kerupuk kulit belum dapat berkembang dengan baik sebagaimana yang diharapkan oleh peneliti, karena sejauh ini usaha kerupuk kulit bisa dikatakan belum terlalu mampu menghadapi persaingan pasar dengan usaha-usaha lainnya yang bergerak 
dibidang industri makanan. Sehingga untuk dapat menguasai pangsa pasar walaupun hanya sebatas memasarkan di dalam Kabupaten saja, usaha ini perlu pengembangan lebih lanjut.

Dari permasalahan yang peneliti temukan dilapangan, peneliti tertarik untuk meneliti tentang proses produksi, kendala-kendala produksi industri kerupuk kulit dan upaya mengatasi kendala produksi industri kerupuk kulit di Jorong Kapalo Nagari Tanjung Barulak Kecamatan Batipuh Kabupaten Tanah Datar.

Sehubungan dari masalah di atas, maka penulis tertarik untuk mengkaji lebih dalam mengenai "Studi Produksi Industri Kerupuk Kulit di Jorong Kapalo Koto Nagari Tanjung Barulak Kecamatan Batipuh Kabupaten Tanah Datar".

\section{METODE PENELITIAN}

Berdasarkan pertanyaan peneliti dan tujuan penelitian, maka penelitian ini digolongkan dalam jenis penelitian deskriptif kualitatif. Deskriptif artinya adalah bertujuan untukmenggambarkan, meringkas berbagai kondisi, berbagai situasi, dan berbagai fenomena yang terjadi.

Moleong

(2004), mendefenisikan metodologi kualitatif sebagai prosedur penelitian yang menghasilkan data deskriptif berupa kata-kata tertulis atau lisan dari orang-orang dan perilaku yang diamati.
Sedangkan menurut Sugiyono (2003), penelitian kualitatif yang dipandang mampu melepaskan apa yang telah difikirkan sebelumnya, dan selanjutnya mampu melihat fenomena-fenomena secara lebih luas dan mendalam sesuai dengan apa yang terjadi dan berkembang pada situasi sosial yang diteliti.

Informan dalam penelitian ini diambil secara purposive, yaitu dipilih dengan pertimbangan dan tujuan tertentu. Peneliti terlebih dahulu mengetahui bahwa orang yang akan dipilih dapat memberikan informasi yang diinginkan.

Pada penelitian ini yang menjadi subjek penelitian adalah pengusaha kerupuk kulit, tenaga kerja industri kerupuk kulit, pembeli kerupuk kulit, Wali Nagari dan Dinas Perindustrian Kabupaten Tanah Datar.

Penelitian ini dilakukan di Jorong Kapalo Koto Nagari Tanjung Barulak Kecamatan Batipuh Kabupaten Tanah Datar dengan alasan karena diantara beberapa Jorong yang ada di Nagari Tanjung Barulak, hanya di Jorong Kapalo Koto yang masih banyak terdapat membuat kerupuk kulit. Penelitian ini dilakukan dari bulan JuliSeptember 2017.

Teknik pengumpulan data yang digunakan dalam penelitian ini yaitu teknik observasi, teknik wawancara, dan teknik dokumentasi. Sedangkan teknik analisis data dalam penelitian ini yaitu reduksi data, 
penyajian data, dan penarikan kesimpulan. Keabsahan data yang digunakan yaitu perpanjangan keikutsertaan, ketekunan pengamatan, diskusi teman sejawat, dan triangilasi.

\section{HASIL DAN PEMBAHASAN \\ Proses Produksi Kerupuk Kulit di Jorong Kapalo Koto Nagari Tanjung Barulak}

a. Proses produksi kerupuk kulit

Kulit sapi dicuci dahulu agar bersih kemudian dipotong menjadi 46 bagian agar lebih mudah dalam pembersihan bulu.Kemudian kulit direbus dengan air yang tidak begitu panas lebih kurang $30^{\circ} \mathrm{C}$ dan diadukaduk dan dibolak-balik sampai rambut dari kulit sapi mudah dikerok.Kulit dikerok atau dikikis dengan pisau sampai bersih kemudian di cuci bersih. Setelah dicuci dipotong-potong berukuran kecil-kecil $(1 \mathrm{~cm}$ x $5 \mathrm{~cm}$ atau sesuai selera).Kulit yang sudah dipotongpotong ukuran kecil direbus kembali dengan air sisa perebusan pertama dan diaduk-aduk sesekali. Bagian atasnya drum ditutup dengan papan. Perebusasan ini membutuhkan waktu lebih kurang 30 menit.Kulit yang sudah direbus selama lebih kurang 30 menit kemudian diangkat.Setelah diangkat kemudian didinginkan beberapa menit sampai panas pada kulit hilang.Setelah didinginkan dibersihkan kembali bulu-bulu halus yang ada pada kulit.Kulit yang sudah di bersihkan dipotong-potong lebih kurang $3 \mathrm{~cm}$ sesuai selera.Kulit yang sudah dipotong-potong kemudian dipisahkan kulit bagian luar dan perut bagian dalamnya.Setelah dipisahkan perut bagian dalam dan bagian luarnya kemudian dipotongpotong lebih kurang $2 \mathrm{~cm}$ atau segi empat sesuai selera.Kulit yang sudah dipotong-potong kemudian dicuci sampai bersih. Untuk kulit bagian luarnya dicuci dengan menggunakan air biasa. Sedangkan perut bagian dalam di cuci dengan menggunakan air panas dan direndam sekitar 15 menit. Setelah itu baru dicuci dengan air biasa sampai bersih dan dikeringkan dengan bakul.Kulit yang telah dicuci dan dikeringkan kemudian diberi garam dan diadukaduk supaya garamnya merata.Kulit yang sudah diberi garam kemudian dijemur sampai kering. Kulit dijemur dengan menggunakan sanggar. Jika cuaca cukup panas, maka waktu penjemuran cukup membutuhkan waktu 3 hari. Salah satu tanda kulit sudah cukup kering adalah kulit sudah sangat keras.

Setelah kulit kering segera dilakukan penggorengan. Proses penggorengan kerupuk kulit ini dilakukan 2 (dua) kali untuk dapat dikonsumsi. Penggorengan awal dengan cara merendam dalam minyak goreng dengan api kompor kecil (mambansah), setelah beberapa waktu dan kerupuk mulai mengembang, api kompor dapat dibesarkan untuk mempercepat kerupuk mengembang. Kerupuk 
yang telah mengembang dapat di angkat dan di tiriskan, kerupuk akan kembali mengecil. Langkah selanjutnya adalah menggoreng kerupuk untuk dapat dikonsumsi, penggorengan ke-2 ini dapat dilakukan seperti menggoreng kerupuk pada umumnya.Kerupuk kulit yang sudah di goreng bisa di kemas atau dipasarkan dan dapat juga langsung dikonsumsi. b. Bahan baku

Bahan Baku yang digunakan oleh pengusaha kerupuk kulit di Jorong Kapalo Koto yaitu kulit sapi dan kulit kerbau. Bahan bakunya diperoleh dari tempat pemotongan sapi Padang Panjang dan Solok dengan cara di pesan dan bahan bakunya langsung diantar ke rumah.

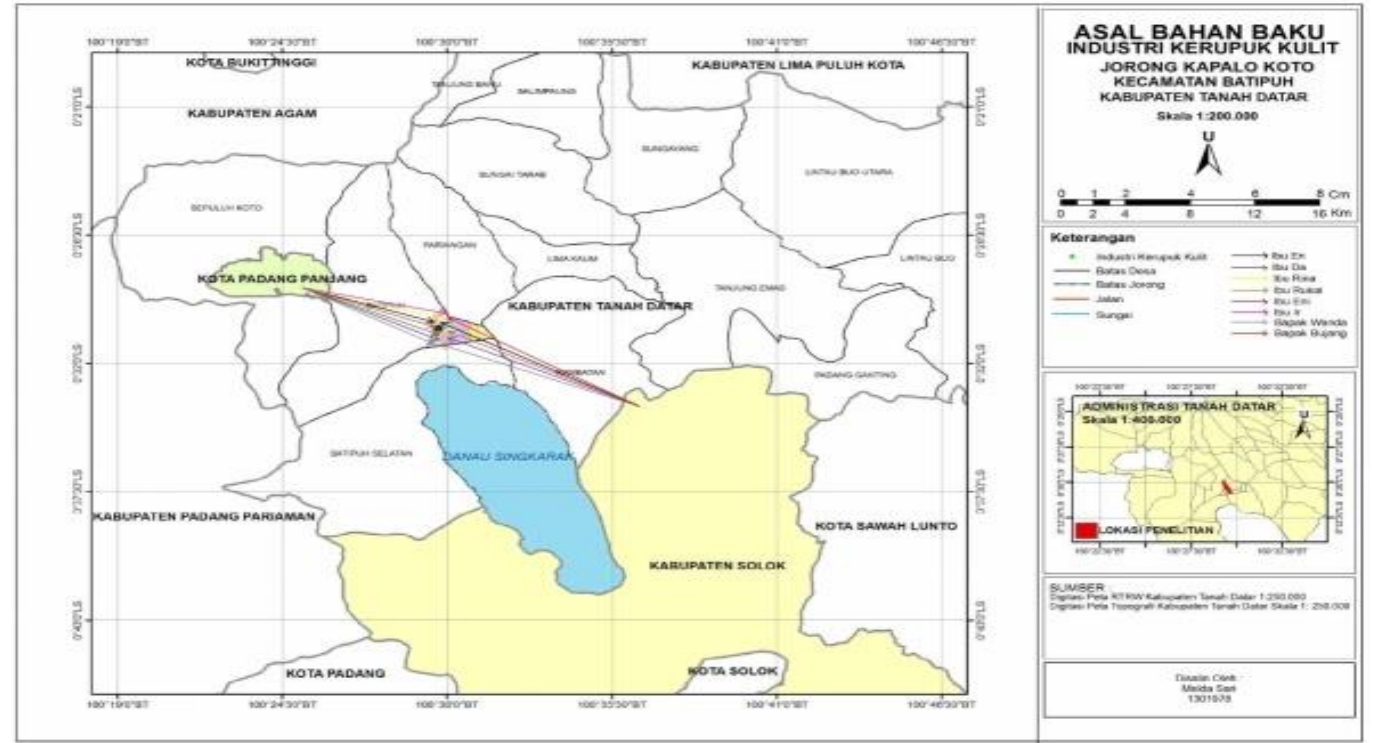

Gambar 1. Asal Bahan Baku Industri Kerupuk Kulit Jorong Kapalo Koto

c. Modal

Modal yang diperlukan untuk membuat kerupuk kulit adalah modal berupa uang. Modal awal yang digunakan oleh pengusaha kerupuk kulit ini ada dari modal sendiri dan dari modal dipinjam dari koperasi atau Bank. Uang tersebut dibelikan alat-alat untuk membuat kerupuk kulit, seperti seperti drum, kayu, pisau, papan, kancah (kuali besar), minyak, kompor, dan lain-lain. Tidak semua pengusaha kerupuk kulit yang memiliki modal sendiri, bahkan dari 8 orang hanya 1 orang yang memakai modal sendiri, dan selebihnya untuk modal awal pengusaha kerupuk kulit meminjam ke koperasi dan Bank.

\section{d. Tenaga kerja}

Tenaga Kerja yang digunakan dalam membuat kerupuk kulit yaitu tenaga kerja yang berasal dari Nagari Tanjung Barulak. Tenaga kerja ini berasal dari Jorong Palembaian, Jorong Tabuh-tabuh, dan Jorong 
guguk Tapung. Sedangkan jumlah tenaga kerja yang dipekerjakan pada hari biasa berjumlah 1 orang. Untuk tenaga kerja yang hanya mengambil kulit sedikit tenaga kerja yang dipergunakan hanya anggota keluarga saja. Pada Hari Raya Haji tenaga kerja yang dipergunakan 1 sampai 2 orang.Tugas yang dilakukan oleh tenaga kerja dalam mengolah kulit yaitu mengikis bulu kulit, membuang bulu, memisahkan kulit luar dan kulit perut bagian dalam dan memotong kulit.

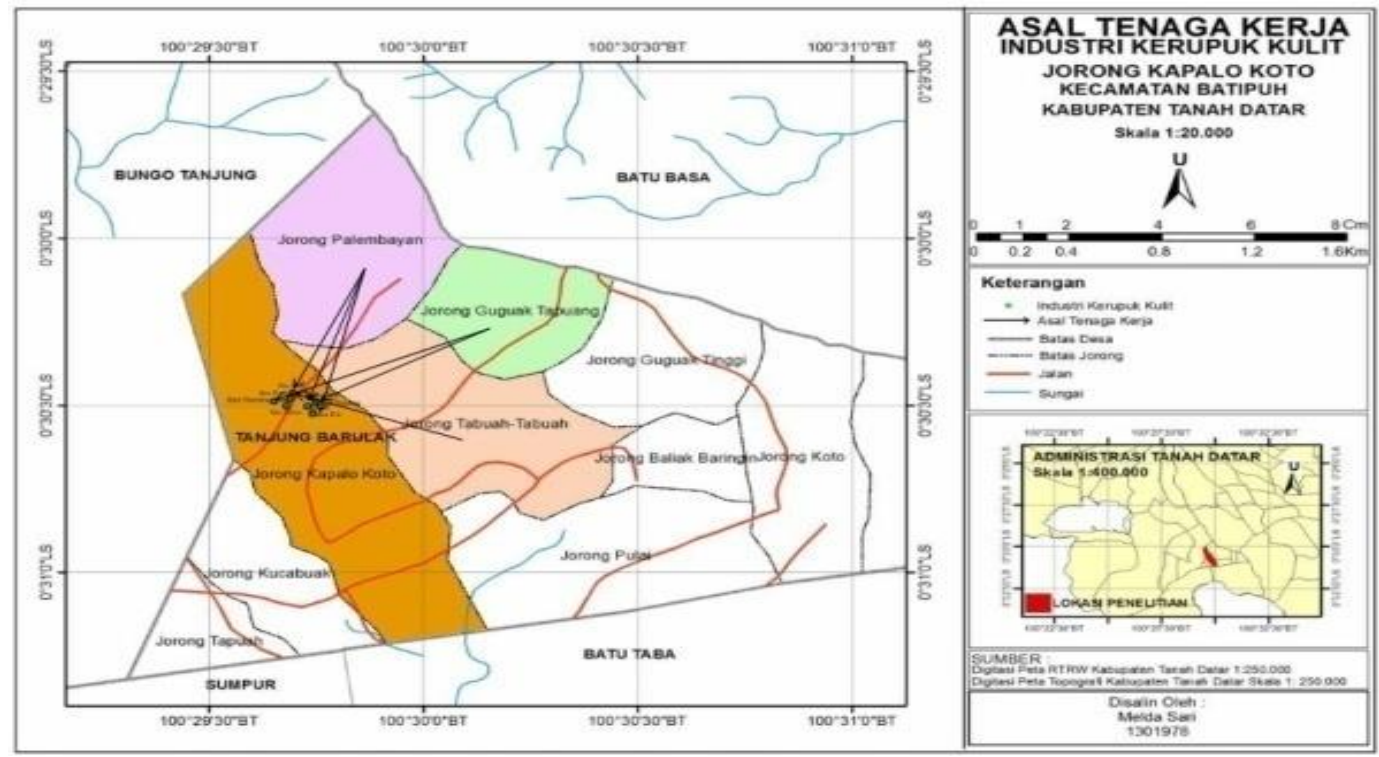

Gambar 2. Asal Tenaga Kerja Industri Kerupuk Kulit Jorong Kapalo Koto

e. Pemasaran yang dilakukan oleh pengusaha kerupuk kulit di Jorong Kapalo Koto ini biasanya dibawa ke pasar-pasar tradisional, warungwarung kecil, Pitalah, Padang Panjang, Solok, Sumani, Malalo, Paninggahan, Simabur dan Padang (supermaket oleh-oleh). Pemasaran terjauh adalah di Padang dengan jarak tempuh 2,5 jam dengan menggunakan mobil. Pemasaran dilakukan oleh pengusaha kerupuk kulit kepada konsumen di rumah dan di pasar-pasar. Pembeli membeli kerupuk kulit biasanya untuk acara syukuran dan untuk oleh-oleh. Pembeli memilih kerupuk kulit yang ada di Jorong Kapalo Koto ini karena kerupuk kulit yang ada di Jorong ini memiliki rasa yang enak, bersih dan tidak amis. 


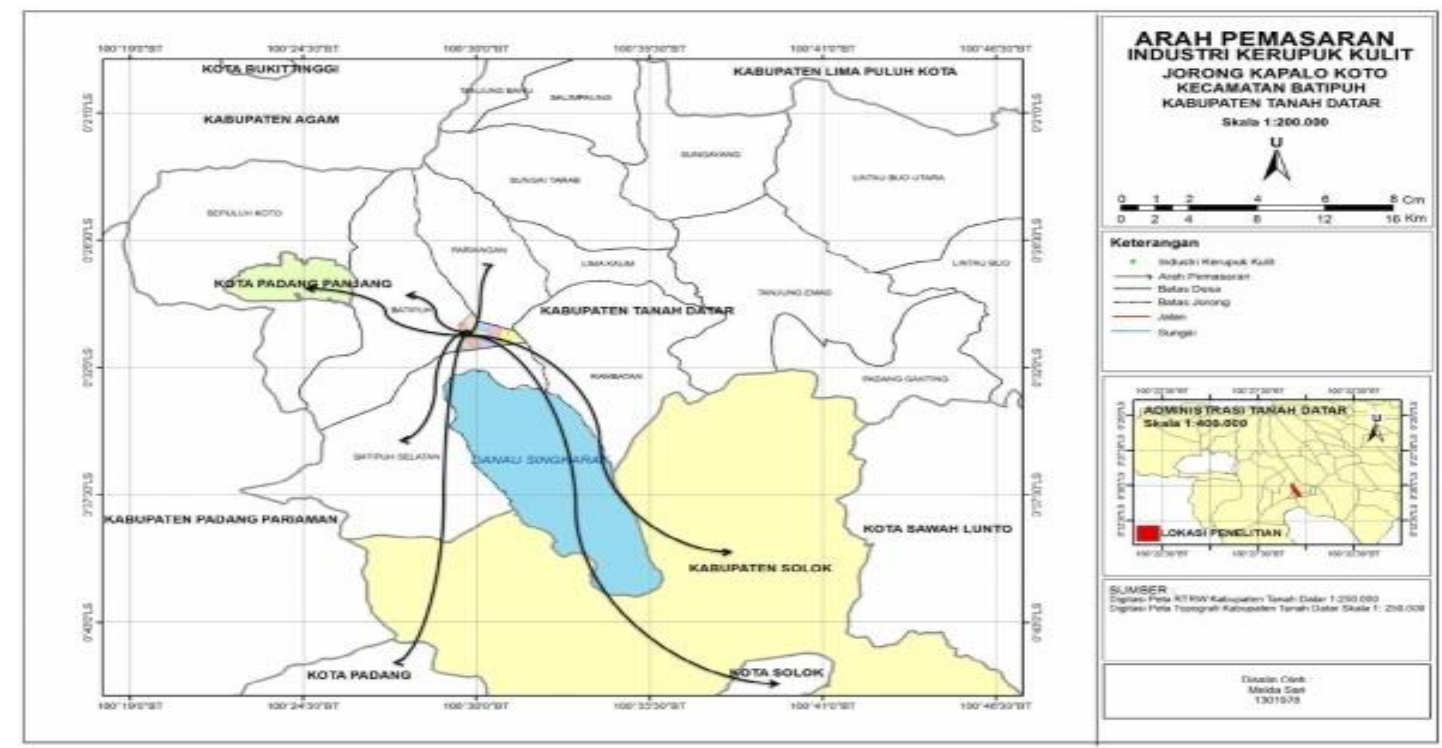

Gambar 3. Arah Pemasaran Industri Kerupuk Kulit Jorong Kapalo Koto

Kendala-kendala

produksi

industri kerupuk kulit di Jorong Kapalo Koto Nagari Tanjung Barulak

a. Kendala yang dialami pengusaha kerupuk kulit di Jorong Kapalo Koto dalam proses pembuatan kerupuk kulit adalah proses pengeringan atau penjemuran ketika hari hujan. Sebab dalam menjemur kulit ini diperlukan kondisi cuaca terik matahari. Penjemuran kulit ini selama 3 hari. Minimal kulit ini harus dapat cahaya matahari selama 2 hari. Kalau tidak warna kulit tidak bagus lagi atau menghitam.

b. Kendala yang dialami pengusaha kerupuk kulit di Jorong Kapalo Koto dalam segi bahan baku yaitu penyediaan bahan baku kurang lancerdisebabkan oleh bertambah banyaknya orang yang membuat kerupuk kulit dan jumlah sapi yang dipotong juga berkurang c. Mengenai modal, kesulitan yang dihadapi oleh pengusaha kerupuk kulit di Jorong Kapalo Koto yaitu kurangnya modal yang dimiliki oleh pengusaha kerupuk kulit untuk pengembangan usaha.

d. Mengenai pemasaran, kendala yang dihadapi oleh pengusaha kerupuk kulit di Jorong Kapalo Koto yaitu kurangnya promosi dan daerah pemasaran belum luas hanya dari mulut ke mulut saja serta kemasan yang masih biasa. Selain itu kerupuk kulit ini belum memiliki label karena terbatasnya modal sehingga belum banyak yang kenal dengan kerupuk kulit yang ada di Jorong Kapalo Koto Nagari Tanjung Barulak.

Upaya-upaya untuk mengatasi kendala produksi industri kerupuk kulit di Jorong Kapalo KotoNagari Tanjung Barulak

a. Upaya yang dilakukan untuk mengatasi proses pengeringan 
atau penjemuran pada hari hujan yaitu dengan menggunakan panas gas tungku.

b. Upaya yang dilakukan untuk mengatasi penyediaan bahan baku yang kurang lancar yaitu dengan mencari bahan baku keluar Kabupaten.

c. Upaya yang dilakukan untuk mengatasi kendala kurangnya modal untuk pengembangan usaha yaitu dengan meminjam uang ke koperasi atau ke Bank.

d. Upaya yang dilakukan untuk mengatasi kurangnya promosi dan belum luasnya wilayah pemasaran yaitu dengan memperluas pemasaran dengan menjalin kerjasama yang baik dengan pengepul-pengepul kerupuk, memasarkan kerupuk kulit ke warung-warung kecil, toko oleholeh, toko pribadi, rumah makan, supermaket sampai mendistribusikan ke luar Kabupaten.

\section{PENUTUP}

\section{Kesimpulan}

a. Proses produksi kerupuk kulit yaitu kulit dicuci dan dibersihkan dari sisa-sisa kotoran kemudian direbus. Proses rebusan berlangsung dua kali, pertama 1015 menit dan rebusan kedua lebih kurang selama 30 menit. Selanjutnya kulit didinginkan, baru dipotong dadu dan dibumbui dengan garam, kemudian dijemur selama 3 hari jika cuaca terik.
Selanjutnya kulit kering direndam dalam minyak goreng dengan api kompor kecil sampai kerupuk mengembang. Setelah itu kerupuk baru digoreng dan siap untuk dikonsumsi, b) sumber bahan baku berasal dari tempat pemotongan sapi Padang Panjang dan Solok. Modal berasal dari dana pribadi, pinjaman Bank, dan koperasi. Tenaga kerja berasal dari daerah sekitar. Pemasaran dilakukan didaerah setempat, Padang Panjang, Solok, Sumani, Malalo, Simabur, Paninggahan, toko oleh-oleh, dan Supermaket Padang.

b. Kendala-kendala produksiindustri kerupuk kulit di Jorong Kapalo Koto yaitu proses pengeringan atau penjemuran pada hari hujan, penyediaan bahan baku yang kurang lancar,kurangnya modal untuk pengembangan usaha, kurangnya promosi dan belum luasnya wilayah pemasaran.

c. Upaya-upaya untuk mengatasi kendala produksi industri kerupuk kulit di Jorong Kapalo Koto yaitu dengan menggunakan panas gas tungku, mencari bahan baku keluar Kabupaten, meminjam uang ke koperasi atau ke Bank, memperluas pemasaran dengan menjalin kerjasama yang baik dengan pengepul-pengepul kerupuk, memasarkan kerupuk kulit ke warung-warung kecil, toko oleh-oleh, toko pribadi, rumah makan, supermaket sampai 
mendistribusikan ke luar Kabupaten.

meningkatkan

pendapatan masyarakat.

\section{SARAN}

a. Bagi pengusaha kerupuk kulit disarankan agar meningkatkan mutu dan kualitas produk kerupuk kulit yang dihasilkan baik dari segi cita rasa maupun kemasan agar dapat merambah pemasaran yang lebih luas.

b. Bagi pengusaha industri kerupuk kulit disarankan untuk lebih sering mengikuti pelatihanpelatihan atau penyuluhan guna menambah ilmu pengetahuan serta wawasan untuk dapat mengembangkan industri kerupuk kulit kedepanya.

c. Bagi pengusaha kerupuk kulit disarankan melakukan jalinan kerjasama usaha antara pengusaha kecil dengan pengusaha menegah atau besar disertai dengan pembinaan dan pengembangan oleh pengusaha besar, sehingga saling memerlukan, menguntungkan, dan memperkuat.

d. Bagi pemerintah Nagari Tanjung Barulak hendaknya dapat membantu pengembangan berbagai bentuk industri kecil yang berbasiskan rumah tangga dengan memberikan bantuan modal atau dengan meminjamkan modal, peralatan, maupun pembinaan terhadap industri karena pekerjaan ini dapat

e. Untuk meningkatkan mutu dan kualitas produk kerupuk kulit yang dihasilkan. Dari segi mutu dapat berupa kehigienis-an produk serta adanya jaminan mutu baik dari pihak Dinas Kesehatan, Badan Pengawas Obat-obatan dan Makanan maupun perolehan sertifikat halal dari Majelis Ulama Indonesia.

DAFTAR PUSTAKA

Anonymous. 2010. Krupuk a.k.a Kerupuk. Wikipedia, the free encyclopedia.

http://en.wikipedia.org/wiki/

Kerupuk, diakses : 15 Maret 2017.

Anonymous. 2011. KERUPUK. Wikipedia Bahasa Indonesia. http://id.wikipedia.org/wiki/K erupuk, diakses 15 Maret 2017.

Dewi, Selfia. 2013. Peluang Pengembangan Industri Kipang di Kecamatan Pasaman Kabupaten Pasaman Barat.Padang :FIS.

Godam. 2006. Organisasi Bisnis Perusahaan. Bandung.

J. Moleong, Lexy. 2004. Metodologi

Penelitian Kualitatif.

Bandung: PT. Remaja Rosdakarya Offset.

Miller dan Meiners. 1997. Teori Ekonomi Mikro Intermediate. Jakarta: Raja Grafindo Persada. 
Nadia, Lula. 2001. Nutrisi dan

Beberapa Kriteria Halal

Kerupuk Kulit Jangek.

(JURNAL) Universitas

Terbuka.

Rangkuti, Freddy. 1997. Analisis SWOT Teknik Membedah

Kasus Bisnis. Jakarta;

Gramedia Pustaka Utama.

Soekartawi. 2001. Pengantar

Agroindustri. Jakarta :PT

Raja Grafindo Persada.

Sugiono. 2003. Metodelogi

PenelitianKualitatif.

Bandung: Alfabeta.

UU No.14 tahun 1969 (pasal 1).

Widati, A.S., Mustakim dan Sri Indriana. 2007. Pengaruh Lama Pengapuran Terhadap Kadar Air, Kadar Protein, Kadar Kalsium, Daya Kembang dan Mutu Organoleptik Kerupuk Rambak Kulit Sapi. JITEK (Jurnal Ilmu dan Teknologi Hasil Ternak, Februari 2007. Vol.2, No.1.(47-56) 